\title{
INVESTMENT: WHAT DRIVES AN INDIVIDUAL TO PREFER AN AVENUE?
}

\section{HRISHIKESH S. KAKDE}

Assistant Professor, Institute of Management and Research, MGM University, Aurangabad, India

\begin{abstract}
Savings and investment propensities play a critical role in achieving dynamic financial market stability. The economic growth of any country is measured by three important variables namely, Income, Savings, and Investment. To have an optimum liquidity level in an economy, it is necessary to mobilize savings and promote investment. Despite traditional theories of finance believe that people act rationally, but in reality, they do not. Both the decision to save and invest can be influenced by deep-seated behavioral biases, personality factors, financial literacy, and external forces. This study was conducted to determine the numerous aspects that influence an individual's investment decision.
\end{abstract}

KEYWORDS: Investment, Investment Behavior, Investment Decision \& Investment Awareness

Received: Jul 23, 2021; Accepted: Aug 13, 2021; Published: Aug 26, 2021; Paper Id.: IJAFMRDEC20214

\section{INTRODUCTION}

Investment is the process of allocating funds to assets that are expected to generate a profit over time.

The expected return, the potential risk factor, and the liquidity of the investment are the most important criteria for investment, but the common goal in all activities is to accumulate wealth. Every individual invests, whether or not the individual doesn't select stock, investments are still made through participation within the pension scheme, opening fixed deposit accounts in banks, and buying of insurance schemes or home (Kothari, 2012). Investors opt for investment avenues that provide them with psychological satisfaction rather than only maximizing their economic benefits. In the past few years, rational factors along with psychological factors have greatly influenced the investment decisions of an individual, causing them most of the time to behave in irrational ways because investors don't make a call, unlike machines. Individual invests in financial products with emotions, passions, enthusiasms, likes and dislikes. Typically, impatient individuals prefer instant gratification (i.e. immediate consumption) rather than keeping their resources for future enjoyment, leading to lower savings, not only do many individuals prefer to live for today at the expense of tomorrow (i.e. they need a bent to prefer smaller, immediate payments to larger, more distant ones) but they often also display inconsistent time preferences. As an example, some people prefer Rs.100 today rather than Rs.150 next week but prefer Rs.150 in period rather than Rs.100 in ten days. Those with a high preference for today are more likely to have master card debt, even with variables like income. they'll also naturally prefer 'instant access' savings products or, if self-aware, the opposite: to lock up their money to avoid the temptation to spend getting all the way down to save is usually perceived as difficult or time-consuming, and procrastination may be a typical reason for not saving. People know they have to save and have the foremost effective intentions of doing so but, when faced with complexity and selection overload, commit to 'do it tomorrow'. 
A few decades back the scope of investment activities was too restricted, as we moved on the financial system developed tremendously, we've also observed structural changes within the economy, employment which led to the introduction of latest financial institutions and modern financial products also. To match our objectives with an accurate investment avenue now each day needs deep insights into institute and products yet and to do to so it became vital what we call it financial literacy of its one-dimension investment awareness to possess the access to information isn't an enormous deal within the age of Google but matching individual objectives and selecting alike options is. The plethora of products, changing nature of availing financial services, setting own goals, and selecting product accordingly seeks attention towards financial literacy, it is not only literacy which is able to aid within the investment decision, perceived behavior and attitude even have an honest impact on investment decision.

\section{SUMMARY OF RESEARCH THAT HAS BEEN REVIEWED}

Considering the set objectives, 85 items were studied for this review. There are several studies carried out in this research area to analyze the various factors affecting the saving and investment patterns, but the studies done earlier fails to justify that whether the investors are able to achieve their investment goals and also the performance of various investment options meeting their expectations.

- Both male and female investors concern about considering past dividends paid by companies while investing in equity shares. Those companies which pay the next rate of dividends are considered good for investment purpose (Jeet Singh et al, 2016).

- Radha Kishan Sharma et al (2014), Rational and irrational factors have an excellent impact on investment decisions, Market Trends, followed by Income level of the Investors, ability to give maximum returns by the selected Investment avenue, location of Investment, Past experience of an investor, Capital Amount of Investment, Risk Tolerance, Advocate Recommendations, awareness about investment avenues, expected returns, Accounting Information, Investment needs, Economical conditions, Investment horizon, Tax exposure, growth of an Industry, Competitive investor performance and least influencing is Government policies. News, Rumors, Trading pressure, Self-image of investment avenues, Mental accounting, Overconfidence, and Dependents behavior respectively.

- Individuals influenced by overconfidence tend to involve in active trading which ends up in fewer returns (Barber \& Odean, 2000).

- The boldness level of individual impacts the investment decision, Generally men exhibit more confidence than women (Barber \& Odean, 2001).

- Investors highly prefer to buy the stocks that are familiar to them, resulting in home bias (Shefrin, 2002) and deficit diversification (Pompian, 2006) Empirical pieces of evidence suggests that, money managers invest within the firms which are familiar to the investors while it's going to yield fewer returns (Hiraki et al., 2005).

- The influence of men in joint investment decisions is more, but the influence gradually decreases within the presence of ladies during implementation (Palma et al., 2011) but the upper the expertise within the field of investments increases the dominance of the spouse effect in deciding (Meier et al., 1999).

- The investor's behavior depends on how the available information is being presented to them and the way much 
they're at risk of taking risks while making decisions (Aruna P et al, 2016).

- Majority of the individuals in India invest through their savings, and savings and investment have a detailed relation. Non-functional consumption and race to use prestige articles and services deplete the amount of savings (Ruddar Dutt, 1972) and so the investment in many cases.

- Marshall et al. (1978) have empirically found investors' perceptions of their rates of return not strongly associated with any socio-economic demographic characteristics, apart from age and income. The number of diversification was positively associated with education levels and age, even after holding income constant; age was a lesser factor than education.

- Robert et al. (1994) classical wealth-maximization criteria are important to investors while investors employ diverse criteria while choosing stocks.

- Radha (1995) Investor chooses an investment avenue in line with their objectives and this objective varies from occupation to occupation and income levels. Amongst all capital appreciation was considered because of the most vital objective.

- The SEBI and NCAER (2000) survey of Indian Investors has reported that safety and liquidity were the first considerations that determined the selection of an asset. Ranked by ascending order of risk perception, fixed deposit accounts within the bank were considered very safe, followed by gold, fixed deposits on non-government companies, mutual funds, equity shares, and debentures. Household's preference for instruments during which they commonly invested matched the danger perception. Bank deposits, which had an appeal across all income classes and tax-saving schemes, were preferred by middle-income and higher-income groups. There was a correlation between the income levels and investments of households in market-related securities.

- People with investment goals, tend to hunt relevant information to scale back the uncertainty level they face in their risky investment, they'll take help from experts for investment decisions Grable J and Joo S. (2001).

- Increase in age tends to extend in less risky investment avenues. Educated people tend to own more investment activities than financially uneducated ones.

- The selection of an Investment Avenue of individual investors mainly depends on the annual income and also the percentage of income allotted for the savings Balaji K (2005).

- Investment decisions and risk tolerance of investors rely upon various factors, to name a few, they are age, sex, income, legal status, education, family background, occupation, and also the environment within which people lived (Giridhari and Sathya (2011).

- In a developing country, people tend to invest high in financial assets rather than investing in physical assets, and particularly, there will be more investment in shares and debentures. But in the case of India, within the initial years after independence, people were highly investing in physical assets than financial assets and now the choice of Indian investor is more or less equally distributed between physical and financial assets (Geetha and Ramesh (2012).

- Past experience of an investor, the work environment of an investor, familiarity with the avenue, and legal status 
among the all found to possess an effect on investment decision.

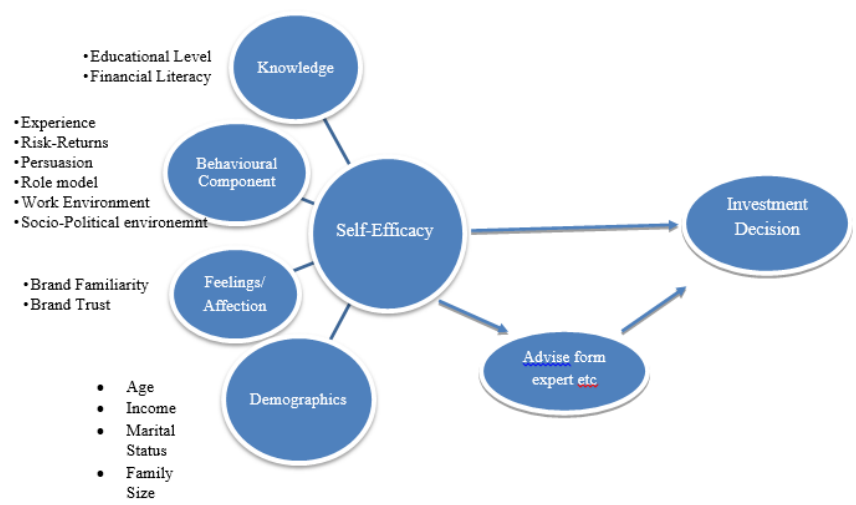

Figure 1: Conceptual Model Showing Determinants of Investment Decision.

\section{METHODOLOGY}

\subsection{Objectives}

- To examine the level of influence of Gender and Income level on investment.

- To analyze the pattern of investment.

- To identify factors affecting investment decisions.

\subsection{Hypothesis}

This research study will test the following hypotheses given below using suitable statistical tests:

- H01: There is no significant association between Gender and Investment awareness level.

- H02: There is no significant association between the income level \&preferences of the investments.

\subsection{Design}

The study was specific to a city named Jalna of Maharashtra state. Salaried class and self-employed class were identified and by using the formula of Kothari(2004) the sample of 372 were drawn for the study.

A structured questionnaire with face-to-face interviews, online survey and observation methods were used for the data collection. Descriptive statistics with chi-square test was used for testing the hypothesis.

\section{DATA ANALYSIS AND INTERPRETATION}

\subsection{Age wise Distribution of the Respondents}

Table 1

\begin{tabular}{|c|c|c|}
\hline Age & No of Respondents & Percentage \\
\hline $20-30$ & 133 & 35.75 \\
\hline $31-40$ & 127 & 34.14 \\
\hline $41-50$ & 76 & 20.43 \\
\hline 51 above & 36 & 9.68 \\
\hline Total & $\mathbf{3 7 2}$ & $\mathbf{1 0 0}$ \\
\hline (Source: - Field survey)
\end{tabular}


4.2 Gender wise Distribution of the Respondents

Table 2

\begin{tabular}{|c|c|c|}
\hline Gender & No of Respondents & Percentage \\
\hline Male & 223 & 59.95 \\
\hline Female & 149 & 40.05 \\
\hline Total & 372 & 100 \\
\hline
\end{tabular}

\subsection{Job/ Employment Sector wise Distribution of the Respondents}

Table 3

\begin{tabular}{|c|c|c|}
\hline Particulars & $\begin{array}{c}\text { No. of } \\
\text { Respondents }\end{array}$ & Percentage \\
\hline Government & 49 & 13.17 \\
\hline Private & 225 & 60.48 \\
\hline Self Employed/ & 54 & 14.52 \\
\hline Semi Government & 43 & 11.56 \\
\hline Total & 372 & 100 \\
\hline
\end{tabular}

4.4 Income wise Distribution of Respondents

Table 4

\begin{tabular}{|c|c|c|}
\hline $\begin{array}{c}\text { Monthly Income (in } \\
\text { INR) }\end{array}$ & $\begin{array}{c}\text { No of } \\
\text { Respondents }\end{array}$ & Percentage \\
\hline Less than 10,000 & 35 & 9.41 \\
\hline 10,001 to 30,000 & 103 & 27.69 \\
\hline 30,001 to 50,000 & 121 & 32.53 \\
\hline 50,001 to $1,00,000$ & 86 & 23.12 \\
\hline $1,00,001$ and above & 27 & 7.26 \\
\hline Total & $\mathbf{3 7 2}$ & $\mathbf{1 0 0}$ \\
\hline (Source: Field Survey) & \\
\hline
\end{tabular}

\subsection{Source of Investment Amount}

Table 5

\begin{tabular}{|c|c|c|}
\hline Investment Source & $\begin{array}{c}\text { No. of } \\
\text { Respondents }\end{array}$ & $\begin{array}{c}\text { Percentage } \\
(\%)\end{array}$ \\
\hline Salary & 192 & 51.61 \\
\hline Existing Savings & 75 & 20.16 \\
\hline Inherited Amount & 67 & 18.02 \\
\hline Personal Borrowing & 38 & 10.21 \\
\hline Total & 372 & 100.00 \\
\hline
\end{tabular}


4.6 Percentage of Respondents Aware of Selected Investment Avenues

Table 6

\begin{tabular}{|l|c|c|}
\hline \multicolumn{1}{|c|}{ Particulars } & $\begin{array}{c}\text { No of } \\
\text { Respondents }\end{array}$ & Percentage \\
\hline Gold & 273 & 73.39 \\
\hline Mutual Fund & 261 & 70.16 \\
\hline Insurance & 300 & 80.65 \\
\hline Real Estate & 285 & 76.61 \\
\hline Bonds & 156 & 41.94 \\
\hline Provident Fund & 217 & 58.33 \\
\hline FD/RD/Saving Deposit & 235 & 63.17 \\
\hline Share/Debentures & 310 & 83.33 \\
\hline (Source: Field Survey) & \multicolumn{2}{|l}{} \\
\hline \multicolumn{2}{|l|}{} \\
\hline
\end{tabular}

4.7 Proportion of Earning to Investment

Table 7

\begin{tabular}{|c|c|c|}
\hline Particulars & $\begin{array}{c}\text { No of } \\
\text { Respondents }\end{array}$ & Percentage \\
\hline $10 \%$ & 68 & 18.28 \\
\hline $20 \%$ & 70 & 18.82 \\
\hline $30 \%$ & 84 & 22.58 \\
\hline $40 \%$ & 109 & 29.30 \\
\hline $50 \%$ & 32 & 8.60 \\
\hline $50 \%$ and above & 9 & 2.42 \\
\hline Total & 372 & 100 \\
\hline
\end{tabular}

4.8 Patterns of Investment time Preferences

Table 8

\begin{tabular}{|c|c|c|}
\hline Tenure & $\begin{array}{c}\text { No of } \\
\text { Respondents }\end{array}$ & Percentage \\
\hline $\begin{array}{l}\text { Short Term } \\
(<1 \text { years })\end{array}$ & 48 & 12.90 \\
\hline $\begin{array}{l}\text { Medium term } \\
\text { (1 to } 3 \text { years) }\end{array}$ & 137 & 36.83 \\
\hline $\begin{array}{l}\text { Long term } \\
\text { (>3 years) }\end{array}$ & 187 & 50.27 \\
\hline Total & 372 & 100 \\
\hline \multicolumn{3}{|c|}{ (Source: Field Survey) } \\
\hline
\end{tabular}

4.9 Reasons for Selection of Specific Avenue

Table 9

\begin{tabular}{|l|c|c|}
\hline Investment Plans & No of Respondents & Percentage \\
\hline Regular Return & 255 & 68.55 \\
\hline Medical Plans & 275 & 73.92 \\
\hline Pension & 317 & 85.22 \\
\hline Contingency & 218 & 58.60 \\
\hline Specific Purpose & 256 & 68.82 \\
\hline Others & 205 & 55.11 \\
\hline (Source: Field Survey) \\
\hline
\end{tabular}


4.10 Advice Preferences for Investment Avenue Selection

Table 10

\begin{tabular}{|c|c|c|}
\hline Particulars & No of Respondents & Percentage \\
\hline Yes & 244 & 65.59 \\
\hline No & 128 & 34.41 \\
\hline Total & 372 & 100 \\
\hline
\end{tabular}

\subsection{Investors Preferences According to Variables under Consideration}

Table 11

\begin{tabular}{|l|c|c|c|c|c|c|c|c|}
\hline \multicolumn{1}{|c|}{ Statements } & SA & A & N & D & SD & Total & WM & Rank \\
\hline $\begin{array}{l}\text { Family structure and } \\
\text { social environment } \\
\text { affect on investment } \\
\text { decisions. }\end{array}$ & 155 & 140 & 33 & 17 & 27 & 372 & 0.509 & II \\
\hline $\begin{array}{l}\text { Financial contents } \\
\text { published on Internet } \\
\text { and media can } \\
\text { positively influence } \\
\text { investor behavior. }\end{array}$ & 85 & 187 & 50 & 39 & 11 & 372 & 0.397 & III \\
\hline $\begin{array}{l}\text { Self confidence in } \\
\text { investment decisions }\end{array}$ & 37 & 127 & 150 & 47 & 11 & 372 & 0.177 & V \\
\hline $\begin{array}{l}\text { Religious and } \\
\text { political views } \\
\text { affected on } \\
\text { investment decision }\end{array}$ & 14 & 148 & 112 & 40 & 58 & 372 & 0.026 & VI \\
\hline $\begin{array}{l}\text { Prefer domestic } \\
\text { investment } \\
\text { institutions over } \\
\text { foreign investment } \\
\text { institution. }\end{array}$ & 88 & 81 & 124 & 35 & 44 & 372 & 0.180 & IV \\
\hline $\begin{array}{l}\text { Government policies } \\
\text { can affection } \\
\text { investment decision }\end{array}$ & 181 & 109 & 64 & 14 & 04 & 372 & 0.603 & I \\
\hline \begin{tabular}{l} 
(Source: Field Survey) \\
\hline
\end{tabular} & & & & & & & & \\
\hline
\end{tabular}

\subsection{What Matters to Investors when they Invest?}

Table 12

\begin{tabular}{|c|l|c|c|}
\hline Sr. No. & \multicolumn{1}{|c|}{ Statement (Variable under Study) } & Respondents & Percentage \\
\hline 1. & Financial Literacy affects investment decision & 352 & 95 \\
\hline 2. & Information about Investment avenue affects investment decision & 335 & 90 \\
\hline 3. & Education level affects investment decision. & 261 & 70 \\
\hline 4. & Past investment experience affects investment decision & 316 & 85 \\
\hline 5. & Work environment impacts investment decision & 223 & 60 \\
\hline 6. & Risk is major constraint in investment decision & 360 & 97 \\
\hline 7. & Brand familiarity affects investment decision & 300 & 80 \\
\hline 8. & Brand Trust affects investment decision & 327 & 88 \\
\hline 9. & Marital Status affects investment decision & 288 & 77 \\
\hline 10. & Income level impacts investment decision & 370 & 99.50 \\
\hline 11. & Despite of all of the above expert advice is necessary & 331 & 89 \\
\hline Source: & Field Survey) & \\
\hline
\end{tabular}


4.13 Factors that does not much Effect Investment Decision

Table 13

\begin{tabular}{|c|l|c|c|}
\hline Sr. No. & \multicolumn{1}{|c|}{ Statement (Variable under Study) } & Respondents & Percentage \\
\hline 1. & Seeing people becoming successful by investing motivates me to invest & 167 & 45 \\
\hline 2. & Socio-political environment investment decision & 170 & 46 \\
\hline 3. & Investment is unnecessary & 25 & 7 \\
\hline 4. & Larger the family size lower is the investment & 145 & 40 \\
\hline 5. & Lower the age higher is the investment & 120 & 32 \\
\hline 6. & Gender has a greater impact of investment decision & 50 & 14 \\
\hline (Source: Field Survey) & \multicolumn{2}{c}{} \\
\hline
\end{tabular}

\subsection{Testing of Hypothesis}

\subsubsection{HO "There is no Significant Association between the Gender and the Investment Awareness Level".}

\section{Observed Frequency}

Table 14

\begin{tabular}{|l|c|c|c|c|}
\hline Gender & Aware & Unaware & Total & Percentage \\
\hline Male & 201 & 22 & 223 & $90.13 \%$ \\
\hline Female & 129 & 20 & 149 & $86.57 \%$ \\
\hline Total & $\mathbf{3 3 0}$ & $\mathbf{4 2}$ & $\mathbf{3 7 2}$ & $\mathbf{8 8 . 7 0 \%}$ \\
\hline (Source: Primary Data)
\end{tabular}

\section{Chi-Square Test}

Table 15

\begin{tabular}{|c|c|c|c|c|}
\hline $\mathbf{O}$ & $\mathbf{E}$ & $(\mathbf{O}-\mathbf{E})$ & $(\mathbf{O}-\mathbf{E}) 2$ & $(\mathbf{O}-\mathbf{E}) 2 / \mathbf{E}$ \\
\hline 201 & 197.823 & 3.177 & 10.093 & 0.0510 \\
\hline 22 & 25.177 & -3.177 & 10.093 & 0.4009 \\
\hline 129 & 132.177 & -3.177 & 10.093 & 0.0764 \\
\hline 20 & 16.823 & 3.177 & 10.093 & 0.5999 \\
\hline & & & Total & $\mathbf{1 . 1 2 8 2}$ \\
\hline
\end{tabular}
fe $(1,1)=(223 \times 330) / 372=197.823$
fe $(1,2)=(223 \times 42) / 372=25.177$
fe $(2,1)=(149 \times 330) / 372=132.177$
fe $(2,2)=(149 \times 42) / 372=16.823$

Degree of freedom: $v=(r-1)(c-1), v=(2-1)(2-1), v=1$

The P-Value is .28816. The result is not significant at $\mathrm{p}<.05$. 
4.14.2 "There is no Significant Association between the Income Level \& Awareness of the Investments".

\section{Observed Frequency}

Table 16

\begin{tabular}{|c|l|c|c|c|}
\hline $\begin{array}{c}\text { Sr. } \\
\text { No. }\end{array}$ & \multicolumn{1}{|c|}{ Income Group } & Aware & Unaware & Total \\
\hline 1. & Less than 10,000 & 24 & 11 & 35 \\
\hline 2. & 10,001 to 30,000 & 91 & 12 & 103 \\
\hline 3. & 30,001 to 50,000 & 110 & 11 & 121 \\
\hline 4. & $\begin{array}{l}50,001 \text { to } \\
1,00,000\end{array}$ & 79 & 7 & 86 \\
\hline 5. & $\begin{array}{l}1,00,001 \text { and } \\
\text { above }\end{array}$ & 26 & 1 & 27 \\
\hline \multicolumn{2}{|c|}{ Total } & $\mathbf{3 3 0}$ & $\mathbf{4 2}$ & $\mathbf{3 7 2}$ \\
\hline (Source: Primary Data) & & & \\
\hline
\end{tabular}

\section{Chi-Square Test}

Table 17

\begin{tabular}{|c|c|c|c|c|}
\hline O & $\mathbf{E}$ & $(\mathbf{O}-\mathrm{E})$ & $(\mathrm{O}-\mathrm{E}) 2$ & $(\mathrm{O}-\mathrm{E}) 2 / \mathrm{E}$ \\
\hline 24 & 31.05 & -7.05 & 49.7025 & 1.6007 \\
\hline 11 & 3.95 & 7.05 & 49.7025 & 12.5829 \\
\hline 91 & 91.37 & -0.37 & 0.1369 & 0.0014 \\
\hline 12 & 11.63 & 0.37 & 0.1369 & 0.0117 \\
\hline 110 & 107.34 & 2.66 & 7.0756 & 0.0659 \\
\hline 11 & 13.66 & -2.66 & 7.0756 & 0.5179 \\
\hline 79 & 76.29 & 2.71 & 7.3441 & 0.0962 \\
\hline 7 & 9.71 & -2.71 & 7.3441 & 0.7563 \\
\hline 26 & 23.95 & 2.05 & 4.2025 & 0.1754 \\
\hline 01 & 3.05 & -2.05 & 4.2025 & 1.3778 \\
\hline \multicolumn{4}{|c|}{ Total } & $\mathbf{1 7 . 1 8 6 2}$ \\
\hline
\end{tabular}

fe $(1,1)=(35 \times 330) / 372=31.04$

fe $(1,2)=(35 \times 42) / 372=3.95$

fe $(2,1)=(103 \times 330) / 372=91.37$

fe $(2,2)=(103 \times 42) / 372=11.63$

fe $(3,1)=(121 \times 330) / 372=107.33$

fe $(3,2)=(121 \times 42) / 372=13.66$

fe $(4,1)=(86 \times 330) / 372=76.29$

fe $(4,2)=(86 x 42) / 372=9.71$

fe $(5,1)=(27 \times 330) / 372=23.95$

fe $(5,2)=(27 \times 42) / 372=3.05$

Degree of freedom: $v=(r-1)(c-1), v=(5-1)(2-1), v=4$ 
The P-Value is .001779 . The result is significant at $\mathrm{p}<.05$.

\section{CONCLUSIONS}

Investment is an economic activity within which every individual is engaged in one form or another. The bulk of individuals no matter their education, status, occupation, etc, are fascinated by investments, savings and income level of respondents influences the investment deciding. While the tendency of investing is earning profits, and everybody who makes investments benefits from it. Those that incur losses haven't managed their funds scientifically and have just followed others blindly. Despite various factors are affecting the investment decision, these factors vary from region to region. Few common to call are experience, risk, returns, attitude towards investment, financial knowledge, self-efficacy affect greatly the investment decision.

During the study researcher found that the gender has nothing to deal with the investment decisions. Majority of the investors in the identified region still follows traditional avenues of investment and it is also found that the increase in the income level leads to search for Investment Avenue and increase in investment, while it has been found that the majority of the factors under study have great impact while selecting the avenue.

The study's main finding is that there is no significant link between gender and investment awareness; nevertheless, there is a strong relationship between investment awareness and investment choices. The study also found that there is a link between income and knowledge of investing options.

According to the findings, there is a strong link between occupation and investment decisions.

\section{REFERENCES}

1. Anitha and Phani.D Bhargavi (2014). “Investors' Perception towards Investment". Global Journal of Finance and Management, 6. 2: 185-190

2. Avinsah N (2014)'Saving pattern and investment preference of Individuals with reference to Hyderabad City' - Scholars Journal of Economics, Business, and Management, pp -294 - 304.

3. Awais M, Laber F, Rasheed N, Khursheed A (2016) Impact of Financial Literacy and Investment Experience on Risk Tolerance and Investment Decisions: Empirical Evidence from Pakistan. International Journal of Economics and Financial 6: 73-79

4. Dashl, MK (2010). "Factors Influencing Investment Decision of Generations in India: An Econometric Study”. International Journal of Business Management and Economic Research, 1.1: 15-26

5. Kothari, Heena. (2012). "Investors Behaviour towards Investment Avenues: A Study with reference to Indore City”. Altius Shodh Journal of Management \& Commerce.1.2: 476-480

6. P. Senthilkumar, (2017) “A Study on Investment Pattern and Awareness of Farmers in Pollachi Thaluk”, International Journal of Interdisciplinary Research in Arts and Humanities, Volume 2, Issue 1, Pp 4-8

7. Thirumagal, P. G., and S. Suresh. "Payoff And The Impact of Various Investment Attributes on Frequency of Investment in Stock Index Futures." International Journal of Mechanical and Production Engineering Research and Development (IJMPERD) Vol 8: 8-15.

8. Hassan, R. B., and A. S. Bello. "The Concept of Mudarabah Investment Deposits." International Journal of Business Management and Research (IJBMR) 4.2: 63-74. 
9. Omar, Arti. "Var analysis on Fii's portfolio decisions-cause effect analysis in Indian context." International Journal of Financial management (IJFM) 5: 1-16.

10. Ramesh, Shruthi, and Smita Kavatekar. "Preferred Investment Avenues Amongst Various Investors-A Study." IMPACT: International Journal of Research in Humanities, Arts and Literature (IMPACT: IJRHAL) 7: 453-462. 
